\title{
Objectives and difficulties in the evaluation of internal communication in Spanish companies
}

\author{
Susana Miquel-Segarra; Cristina Aced-Toledano
}

Nota: Este artículo se puede leer en español en:

http://www.elprofesionaldelainformacion.com/contenidos/2019/sep/miquel-aced_es.pdf

How to cite this article:

Miquel-Segarra, Susana; Aced-Toledano, Cristina (2019). "Objectives and difficulties in the evaluation of internal communication in Spanish companies". El profesional de la información, v. 28, n. 5, e280521.

https://doi.org/10.3145/epi.2019.sep.21

Manuscript received on $10^{\text {th }}$ April 2019 Accepted on $19^{\text {th }}$ September 2019

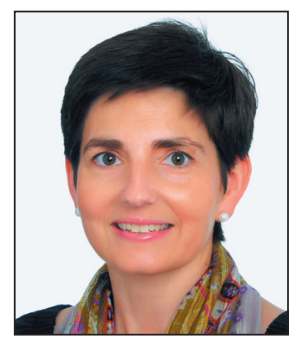

Susana Miquel-Segarra $\square$ https://orcid.org/0000-0002-0337-7503

Universitat Jaume I

Facultad de Ciencias Humanas y Sociales Departamento de Ciencias de la Comunicación, Spain smiquel@uji.es

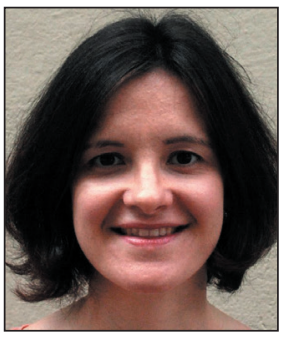

Cristina Aced-Toledano https://orcid.org/0000-0002-2732-5708

Universitat Oberta de Catalunya Facultat de Ciències de la Informació i la Comunicació, Spain caced@uoc.edu

\begin{abstract}
Recent studies confirm that business leaders are increasingly interested in internal communication (IC). However, in order for IC to continue evolving, the ability to demonstrate its impact on the income statement through the measurement and the evaluation of its actions is essential. This work analyses the objectives evaluated by the IC departments, the evaluation procedures and the barriers to measuring effectiveness in a study carried out with 118 IC leaders in Spain. The results show that evaluation focuses on the employees and their reactions, and that the main obstacle in measuring is the lack of appropriate tools. In addition, evaluation largely depends on the type of company and how the department is organized.
\end{abstract}

\section{Keywords}

Internal communication; Organizational communication; Corporate communication; Professional profile; Skills; Abilities; Evaluation; Companies; Firms; Tools; Metrics; Measurement.

\section{Introduction}

Professionals and academics of internal communication (IC) increasingly see IC as a key strategic value for organisations (Adecec, 2019). Numerous investigations reveal the advantages and potential of IC and, among others, affirm that it helps employees to share information, establish relationships and generate meanings (Berger, 2008); to promote interactivity (Capriotti, 1998); reaffirm one's own identity and organisational values (Álvarez-Nobell; Lesta, 2011; Berger, 2008); and create a positive organisational climate (Charry-Condor, 2018). In addition, they indicate that IC helps to make decisions, resolve problems, and manage the processes of change (Men, 2014; Men; Stacks, 2014; Capriotti, 1998). In fact, in a society as dynamic as the current one, IC is seen as a vital aspect of addressing the changes that occur in any organisation (Elving, 2005; Daly; Teague; Kitchen, 2003). However, authors like Álvarez-Nobell \& Lesta point out that

"to say that internal communication contributes to increasing the value of the organisations is without a doubt a very attractive, but also insufficient, statement" (Álvarez-Nobell; Lesta, 2011, p. 12). 
IC has to be flexible and tailored to the needs of the business if it wants to be really effective (Sedej; Justinek, 2013; Ruck y Welch, 2012), but it also has to provide relevant data that will allow the organisation to take decisions that are not solely based on intuition (Castillo-Esparcia; Villabona-Beltrán, 2018; Álvarez-Nobell; Lesta, 2011). Therefore, the IC needs to perform periodical planned measurements to evaluate the effectiveness of the messages and means it uses and, above all, the contributions it realises to reach a company's strategic goals (Zerfass; Verčič; Volk, 2017; Watson; Noble, 2014) and its contribution to the profit and loss account (Cuenca; Verazzi, 2018, Martínez-Martínez: Fernández-Hurtado, 2018; Slijepčević; Bovan; Radojević, 2018; IC Kollectif, 2018; Berceruelo, 2014). In addition, the evaluation of IC reinforces its strategic value since

"knowing both the positive and negative results makes it possible to set priorities, make decisions, and carry out planning previsions" (Álvarez-Nobell; Lesta, 2011, p. 12).

On the other hand, Marca et al. (2017) \& Gómez-De-la-Fuente \& Túñez-López (2012) assert that the evaluation of communication is essential when the time comes to be accountable, demonstrate efficacy and know the impact that IC has in the corporate and business strategy of the organisation, because

"without measurement it is not possible to manage communication" (Adecec, 2016, p. 7).

Therefore, evaluation has become one of the main challenges faced by professionals in the field, as various studies suggest (IC Kollectif, 2019; Nelli, 2018; VMAGroup, 2018; Zerfass et al., 2018).

In this context, the figure of the director of communication is fundamental. One of their challenges, highlighted in the European communication monitor reports from 2010, analysed in Castillo-Esparcia and Villabona-Beltrán (2018), is to convert the challenges and strategies of the management of the company's objectives into communication policies at the service of its intangible assets (Carrillo-Durán; Nuño-Moral, 2010). For that reason, it is currently demanded

“integrating communication to achieve the company's general strategy" (Carrillo-Durán, 2016, p. 273),

and this requires the professional (dircom)

"to know, understand and achieve the mastery of the managerial logic adopted by the organisation and its conception of results/value" (Álvarez-Nobell; Lesta, 2011, p. 25).

However, the current situation does not reflect any improvement in this aspect. Recent research (Gatehouse, 2019; IC Kollectif, 2019; O'Neil et al., 2018) shows the low impact the evaluation and measurement of the management of communication in organisations has had. European companies rarely measure the results of internal communication, and when they do, they do not analyse what really matters (IC Kollectif, 2019). Furthermore, in a study conducted by Castillo-Esparcia and Villabona-Beltrán (2018) which analyses the ten versions of the reports of the European communication monitor (2010-2017), it can be seen that the majority of European enterprises use evaluation results solely

"to measure the success of the communication activities (66\%), to do the planning of forthcoming activities (62.9\%), to explain the value of communication to senior managers and internal clients (59.5\%), and analyse the goals and the direction of the communication strategies (58\%)" (Zerfass et al., 2015, in Castillo-Esparcia y Villabona-Beltrán, 2018, p. 150),

leaving aside the influence this has on the organisational strategic outcomes.

In the specific field of IC the data is similar. Few organisations evaluate the results of IC and even less measure its activities drawing from the objectives set by the organisation (Castillo-Esparcia; Villabona-Beltrán, 2018; Simancas-González; García-López, 2017; Castillo-Esparcia; Álvarez-Nobell, 2014; Álvarez-Nobell; Lesta, 2011). Thus, measurement continues to be one of the most important neglected duties in IC, despite its relevance in the corporate sphere (Gatehouse, 2019; Cuenca; Verazzi, 2018).

In conclusion, it is convenient to carry out an analysis of how companies conduct IC evaluations. The overall objective of this research focuses on knowing how companies in Spain evaluate the effectiveness of the IC strategies that are carried out to determine what the priorities facing these departments in the medium term are. In particular, it aims to:

- Identify the IC objectives companies currently evaluate by and the evaluation procedures employed.

- Define the main barriers professionals encounter in measuring the effectiveness of IC.

The intention is also to carry out a prospective analysis to reach the following objectives:

- Describe the role of IC in the company.

- Detect the priorities that company IC teams have over the next three years and ascertain whether the measurement of IC is amongst them. 
Specifically, this research analyses these variables according to the structural characteristics of the departments and the companies the professionals who participated in the research belong to.

\section{Method}

\subsection{Samples}

The sample is made up of 118 professionals who are responsible for the management of IC. Some $60.2 \%$ of participants are women and $39.8 \%$ men. In terms of age,

- $1.7 \%$ are less than 25 years of age,

- $4.2 \%$ from 26 to 30 ,

- $17 \%$ from 31 to 40 ,

- $68.7 \%$ from 41 to 50 ,

- $0.8 \%$ from 51 to 60 , and

- $7.6 \%$ over 60 .

All participants have a university degree; the most common are journalism (52.5\%), advertising and public relations $(22.9 \%)$, economics $(10.2 \%)$ and law $(6.8 \%)$. The academic formation of $84.7 \%$ of them is completed with post-graduate studies in corporate communication (47.4\%), marketing and sales management (15.3\%), social networking (8.5\%), MBA (6.8\%) and $H R(6.8 \%)$.

Some $45.8 \%$ of the companies to which participants belong are multinational and $54.2 \%$ of them national. In terms of size,

- $72 \%$ are large companies (more than 250 employees),

- $9.3 \%$ medium (51 to 250 employees),

- $10.2 \%$ small (11 to 50 employees), and

- $8.5 \%$ micro-enterprises (of 1 to 10 employees).

The main sectors of activity of the companies which the participants are from are

- consulting (11.9\%),

- education (11\%),

- health $(8.5 \%)$,

- food (7.6\%),

- public government (7.6\%),

- financial services (6.8\%),

- technology (5.9\%),

- infrastructure, transport and logistics (5.1\%),

- automotive (5.1\%),

- NGOs (4.2\%),

- ICT (4.2\%), and

- other sectors (22\%).

\subsection{Procedure}

The research has been conducted on the basis of the data from the Study on the state of internal communication in Spain carried out by the Association of Directors of Communication (Dircom) during the first quarter of 2018 with the aim of knowing the current state of the discipline, and to highlight and maximise IC as a strategic role and company policy.

The design of the online questionnaire is based on research previously carried out by the Associazione per lo Sviluppo delle Comunicazioni Aziendali in Italia (Ascai) and the European Association of Internal Communication (Feiea) (Nelli, 2018). The questionnaire, consisting of 37 questions, is structured in five sections:

- positioning of the IC team;

- strategies, objectives and activities;

- assessment processes;

- business context;

- and priorities, problems and challenges faced.

Data collection was carried out between February 22, 2018 and March 22 of the same year. The time required for completion was 20 minutes. Confidential and anonymous treatment of information was guaranteed in accordance with Organic Law 15/1999 on the Protection of Personal Data. Sampling of the study has been non-probabilistic by self-selection (Couper, 2000; Rodríguez-Jaume; González-Río, 2014). The link to the questionnaire has been sent online to the members of the Association of Directors of Communication (Dircom) (approximately 1,022) to be completed by those professionals who have responsibilities in the management of IC teams in their company (Trust level: 95\%; sampling error $8.5 \%$; $\mathrm{p}=\mathrm{q}=0.5)$. 


\subsection{Data analysis}

In the first phase there has been a descriptive analysis of the type of evaluations carried out, the quality, effectiveness and the role they have and the priorities that are imposed on the IC teams in the companies in the study. Then, to study the differences between companies according to their structural characteristics and after checking the assumption of homogeneity of variance, since the items are in interval scale the Student $t$ test for independent samples and anovas of a factor of the study's variables have been applied.

Following that, to analyse whether there are differences in the evaluation of the IC teams the enterprises carry out, and the quality and the purpose they have, according to their level of effectiveness the Student $t$ test for independent samples has been applied after checking the assumption of the homogeneity of variance. Finally, in order to know whether the effectiveness that the IC team has in the company is related to the priorities they have highlighted, the chi-square test has been applied.

The value of significance is set to $<0.05$.

The analysis of the data was performed with the SPSS statistical package, version 21.0.

\section{Results}

Firstly, a description of the profiles and the structures of the IC departments analysed in the present study has been performed. The results show that 85.6 per cent of the participating enterprises have a department that is dedicated to IC. However, the size of the departments is very small. In $35.6 \%$ the IC departments are composed of a single person, in $42.4 \%$ there are two to three people and in $22 \%$ there are four or more. Furthermore, in $39 \%$ of companies the IC department has the support of agencies and external consultants.

When one analyses the structure of their own departments the data indicates that $62.7 \%$ of the companies manage IC with what the Dircom association defines as a centralised scheme. In this type of structure there is a central IC team that defines the strategies as well as corporate content and the local departments which, in each case, adapt them. On the contrary, coordinated management, in which the central team only acts as a reference, only occurs in $25.4 \%$ of the organisations analysed. Finally, only $11.9 \%$ of the companies undertake decentralised management where each local team has its own IC director that defines strategies and content.

\subsection{Evaluation of the internal communication: objectives, instruments and barriers}

The participants valued a series of IC objectives that were evaluated to measure their effectiveness in the company. It was found that among the objectives that companies use to set out to measure the effectiveness of the strategies developed (Figure 1); the satisfaction/involvement of employees is preferred. Secondly, other aspects such as the use of the intranet and the employees' understanding of the key messages of the company are analysed. These variables evaluate the effectiveness of the programmes and actions of IC in

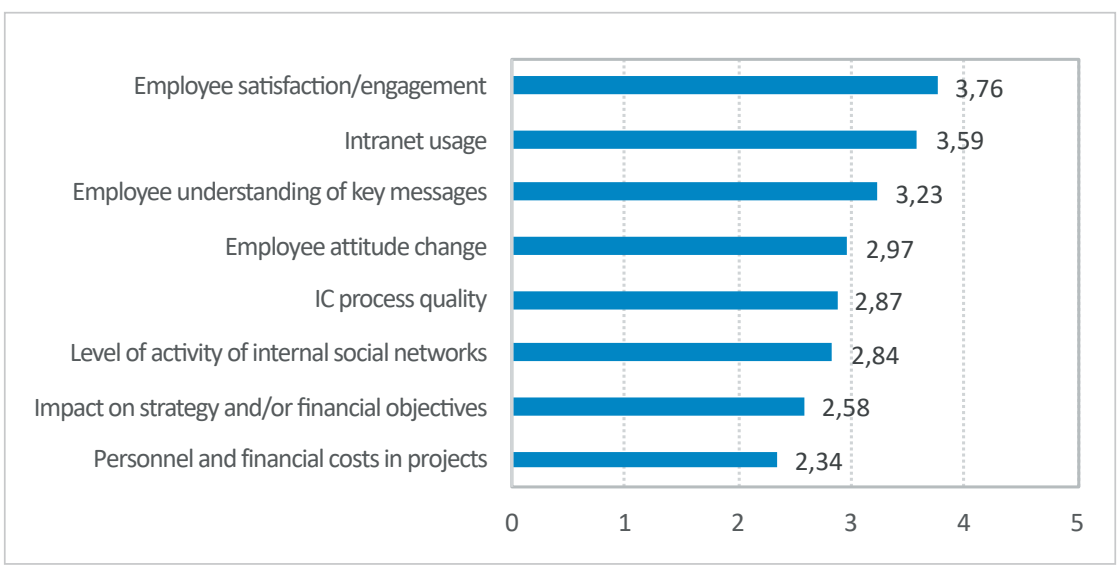

Figure 1. The average level of evaluation of IC objectives to measure effectiveness From $1=$ low to $5=$ high. themselves. On the contrary, aspects related to business objectives such as the financial and personnel costs invested for the undertakings of projects are the least analysed.

On analysing the results according to the land-based locations of the organisations, statistically significant differences are detected:

- multinational enterprises measure worker satisfaction more than national companies (4.13 versus 3.45$)(t(115)=$ -2.99; $\mathrm{p}=0.003 ;(d=0.56)$,

- intranet usage (3.92 versus 3.31) (t $(114.802)=-2.39 ; p=0.018 ; d=0.43)$, and

- employee understanding of key messages (3.58 versus 2.94) (t $(114)=-2,61 ; p=0.010 ;(d=0.48)$.

It is also noted that the evaluation carried out by companies on the financial and personnel costs vary depending on the size of the entity $\left(F(2 ; 113)=7.927 ; p=0.001 ; \eta^{2}=0.12\right)$. In particular, there are differences between small and large companies, 3.23 versus 2.12; $(p<0.001)$.

The data also reveals that companies that resort to external consultants mainly contract them to evaluate employee at- 
titude change (3.29 versus 2.77$)$ (t (114) $=2.03 ; p=0.045 ; d=0.39)$. On the other hand, companies with specific IC departments, or at least with a person dedicated to this function, include the evaluation of tactical aspects such as intranet usage among their objectives (3.83 versus 2.18 ) (t (115) $=4.796 ; \mathrm{p}<0.001 ; \mathrm{d}=1.26)$ and employee understanding of key messages (3.39 versus 2.29) $(\mathrm{t}(114)=3.185 ; \mathrm{p}=0.002 ; \mathrm{d}=0.84)$.

On the other hand, the instruments and procedures companies most frequently use to assess the effectiveness of the IC have been the feedback on events and employee surveys. As shown in Figure 2, the cost/ benefit analyses are the indicators that are least frequently used.

The data reflects that multinationals rely more on the use of employee surveys than companies of national scope (3.69 versus 2.98$)(t(115)=-2.807 ; p=0.006 ; d=0.53)$. In addition, it is noted that the use of the cost/benefit analysis varies according to the size of the work centres $\left(F(2 ; 113)=4.012 ; p=0.021 ; \eta^{2}=0.07\right)$; differences in this use are recorded between small and medium-sized enterprises ( 2.86 compared to $1.60 ; p=0.031$ ).

With regards to the measuring instruments most used by the consultants are those that allow the evaluation of the intranet analytics (3.60 versus 2.74) (t $(115)=3.296 ; p=0.001 ; d=0.62)$. Companies that have IC departments rely more on employee surveys (3.48 versus 2.29) $(\mathrm{t}(115)=3.407 ; \mathrm{p}=0.001 ;(\mathrm{d}=0.90)$, intranet analytics $(3.26$ versus 1.94$)(\mathrm{t}(115)=$ $3.684 ; p<0,001 ; d=0.97)$, feedback on events (3.66 versus 2.59) $(t(114)=3.039 ; p=0.003 ;(d=0.80)$ and the analytics of the sending of newsletters (3.33 versus 2.24) $(t(116)=2.743 ; p=0.007 ; d=0.72)$.

Finally, the results reflect that the key barriers that companies have against performing an effective assessment of IC are a lack of adequate tools to do so and not understanding exactly what ought to be measured. However, the costs in themselves that an evaluation generates are not listed as a priority problem (Figure 3).

The data also show that national firms encounter more obstacles than international ones. The main reasons are the following:

- not understanding what to measure (3.41 versus 2.78$)(t(116)=2.666 ; p=0.009 ; d=0.50)$,

- because the evaluation takes a lot of time (2.92 versus 2.44$)(t(116)=2.041 ; p=0.044 ; d=0.38)$,

- because the reports required for the evaluations cannot be carried out (2.84 versus 1.96) (t $(112.144)=3.874 ; p<$ 0,$001 ; d=0.69$ ) and,

- because of the costs generated by the evaluation of IC (2.63 versus 2.00$)(t(115.920)=2.784 ; p=0.006 ; d=0.51)$.

On the other hand, it can be observed that the companies that do not assign IC to a specific body have more difficulties in knowing what they have to evaluate ( 3.76 versus 3.01 ) $(t(116)=-2.238 ; p=0.027 ; d=0.58$ ) and point out the impossibility of carrying out the reports needed for the evaluation as an obstacle $(3.24$ versus 2.31$)(t(19.003)=-2,184 ; p=0.042 ; d=0.72)$.

Another peculiarity detected is that multinational companies value their IC teams more than the nationals (3.56 versus 3.05) (t (112.760) $=-2,523 ; p=0.013 ; d=0.45)$.

The valuation of their IC teams also varies according to company size $(F(2 ; 115)=3.288 ; p=$ $\left.0.041 ; \eta^{2}=0.05\right)$; in particular the differences are between large and medium-sized enterprises, values being higher for IC teams in larger companies than for the appraisal by medium-sized ones (3.28 compared to 2.45; p $=0.031)$.

\subsection{The role of IC}

Participants feel that the effectiveness of IC strategies to support the business objectives is remarkable (3.44 on average about 5

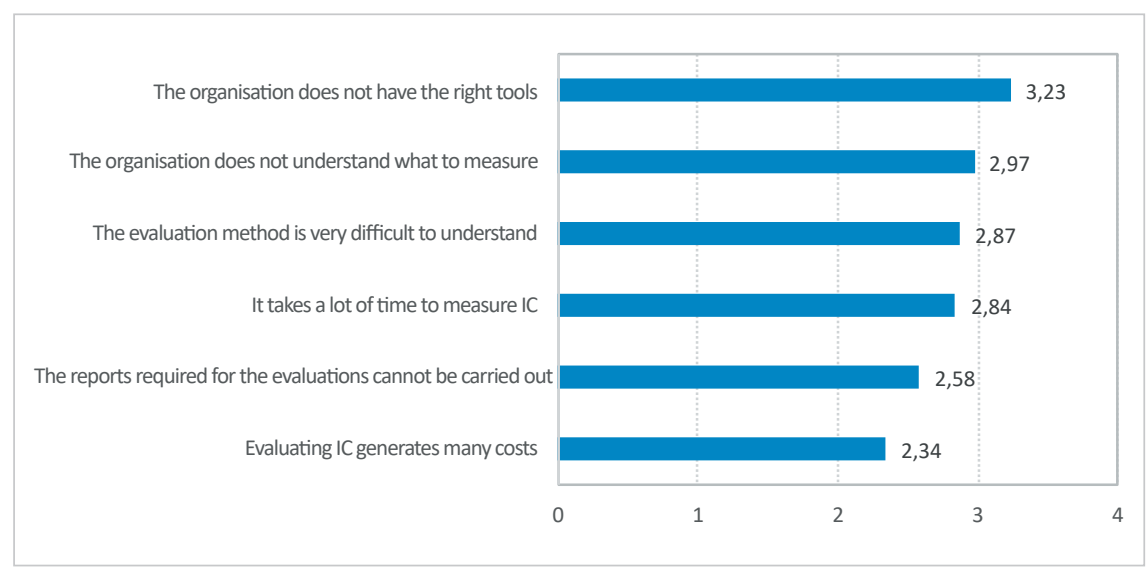

Figure 3. Average rating of the barriers affecting the effective evaluation of IC From 1 = strongly disagree to 5 = fully agree. 
(SD = 0.92). In this regard, the main role given to IC is the one of supporting a company's strategic objectives $(M=3.88)$; they also point to the importance of IC as a relevant aspect in supporting and influencing the senior management team ( $M=3.73 / 3.64)$ (Table 1).

Table 1. Evaluating the role of IC in the companies of the study

\begin{tabular}{|c|c|c|}
\hline & & \\
\hline & Mean & SD \\
\hline IC supports the company's strategic objectives & 3.88 & 1.13 \\
\hline IC allows senior managers to recognize the inherent communication aspect in all decisions and activities. & 3.73 & 1.16 \\
\hline IC supports senior managers by providing them with information to take decisions or act & 3.65 & 1.15 \\
\hline IC advises managers on how to act in certain communicative challenges & 3.64 & 1.23 \\
\hline $\mathrm{IC}$ is a key piece in the digitalization of the company & 3.59 & 1.35 \\
\hline IC plays a very important role in the overall running of the company & 3.58 & 1.27 \\
\hline The person responsible for IC is involved from the onset in the strategic plans & 3.25 & 1.33 \\
\hline Senior managers take the IC recommendations very seriously & 3.24 & 1.17 \\
\hline Senior managers view the IC team as trusted advisers & 3.23 & 1.34 \\
\hline The head of IC is always invited to senior level meetings of senior officials dealing with strategic planning issues & 3.03 & 1.36 \\
\hline The IC team acts only when problems occur & 2.56 & 1.44 \\
\hline
\end{tabular}

From 1 = strongly disagree to 5 = fully agree.

$\mathrm{SD}=$ Standard deviation

It should be noted that, in the face of the opinion of the international companies (2.22), national enterprises (2.84) consider IC is not viewed as a strategic factor. At the same time, Spanish companies consider IC is to be used only when crisis situations or problems arise $(\mathrm{t}(116)=2.380 ; p=0.019 ; \mathrm{d}=0.44)$. On the other hand, research participants have valued the quality and ability of the IC team in a positive way $(3.28(S D=1.15)$, the valuation of companies that work with external consultants being superior to those that do not count on them (3.54 versus 3.11) (t $(116)=2.024 ; p=0.045 ; d=0.38$ )

\subsection{Priorities for internal communication}

The analysis shows that $95 \%$ of the circumstances raised (Table 2 ) are priority issues ${ }^{1}$ for, at least, more than half of the companies. The main objectives that arise in the IC departments in their companies are "aligning IC to the business strategy" ( $82.2 \%$ of the entities) and "strengthening the role of communication to support the senior managers' decision making" (80.5\%).

Table 2. Priority objectives for IC departments in the next three years (\%)

\begin{tabular}{|c|c|c|c|}
\hline & Hign priority & Ivieaium & secondary \\
\hline 1. Aligning IC to the business strategy & 82.2 & 11.9 & 5.9 \\
\hline 2. Strengthening the role of communication to support the senior managers' decision making & 80.5 & 16.1 & 3.4 \\
\hline 3. Managing digital-evolution and the media & 79.7 & 14.4 & 5.9 \\
\hline 4. Adapting to the speed and volume of information flow & 77.1 & 13.6 & 9.3 \\
\hline 5. Establishing new methods to evaluate and demonstrate the value of communication & 74.6 & 18.6 & 6.8 \\
\hline 6. Getting to the employees by using mobile technology & 74.6 & 11.9 & 13.6 \\
\hline 7. Taking measures that inspire employees to create and share valuable content & 72.9 & 16.9 & 10.2 \\
\hline 8. Helping senior managers and team leaders to build their communicative abilities & 72.1 & 20.3 & 7.6 \\
\hline 9. Aligning IC to the communication and external business actions & 71.2 & 18.6 & 10.2 \\
\hline 10. Integrating employee generated employee content into corporate communication & 67.8 & 24.6 & 7.6 \\
\hline 11. Explaining the value of IC to the directors & 65.3 & 17.8 & 16.9 \\
\hline 12. Implementing advanced monitoring and active listening strategies & 63.6 & 27.1 & 9.3 \\
\hline 13. Meeting the demand for more transparency and active audiences & 63.5 & 29.7 & 6.8 \\
\hline 14. Teaching employees to use social networks to generate content of value & 61.0 & 21.2 & 17.8 \\
\hline 15. Combining the need to address more audiences and channels with limited resources & 56.8 & 32.2 & 11.0 \\
\hline 16. Replacing written media with digital media & 56.8 & 26.3 & 16.9 \\
\hline 17. Managing the inclusion of "digital natives" & 53.4 & 30.5 & 16.1 \\
\hline 18. Supporting the integration of multicultural people in the company & 51.7 & 28.8 & 19.5 \\
\hline 19. Implementing an ethical code for the processes and actions of IC & 50.8 & 24.6 & 24.6 \\
\hline 20. Identifying the sustainability policies of the IC process & 48.3 & 33.9 & 17.8 \\
\hline
\end{tabular}

From 1 = not important to 5 = very important.

*Note: Priority objectives are evaluated with 4 and 5, medium importance evaluated with 3 and secondary importance with 1 and 2. 
In addition, $74.0 \%$ of respondents considered "establishing new methods to evaluate and demonstrate the value of communication" as priority objectives and a major challenge in coming years

Finally, in order for the study to look deeper, items have been re-coded that assess the self-perceived effectiveness of the IC teams as a dichotomous variable distinguishing between highly effective IC teams (with values of 4 or 5) and those IC teams with a medium-low effectiveness (with values from 1 to 3 ).

The data reflects that firms with higher rates of effectiveness coincide in a series of characteristics (Table 3): tending to assess IC objectives with greater frequency, using a wider range of evaluation procedures and, at the same time, encountering fewer barriers to carrying them out.

Table 3. Descriptive statistics and t-tests of the analysed variables

\begin{tabular}{|c|c|c|c|c|c|c|}
\hline & \multicolumn{2}{|c|}{ High effectiveness** } & \multicolumn{2}{|c|}{ Medium-low effectiveness } & \multirow{2}{*}{$\mathbf{t}$} & \multirow{2}{*}{$\mathbf{p}$} \\
\hline & $\mathbf{N}$ & M (SD) & $\mathbf{N}$ & M (SD) & & \\
\hline \multicolumn{7}{|l|}{ IC objectives evaluated } \\
\hline Employee satisfaction/engagement & 59 & $4.24(0.99)$ & 58 & $3.28(1.34)$ & 4.421 & $0.000 *$ \\
\hline Intranet usage & 59 & $4.24(1.01)$ & 58 & $2.93(1.51)$ & 5.501 & $0.000 *$ \\
\hline Employee understanding of key messages & 58 & $3.69(1.14)$ & 58 & $2.78(1.43)$ & 3.807 & $0.000 *$ \\
\hline Employee attitude change & 58 & $3.31(1.20)$ & 58 & $2.64(1.41)$ & 2.763 & $0.007^{*}$ \\
\hline IC process quality & 58 & $3.14(1.30)$ & 58 & $2.60(1.35)$ & 2.169 & $0.032 *$ \\
\hline Enterprise social networks metrics & 59 & $3.22(1.43)$ & 57 & $2.44(1.39)$ & 2.988 & $0.003^{*}$ \\
\hline Impact on strategy and/or financial objectives & 58 & $3.05(1.13)$ & 58 & $2.10(1.18)$ & 4.419 & $0.000 *$ \\
\hline Personnel and financial costs in projects & 58 & $2.47(1.17)$ & 58 & $2.22(1.29)$ & 1.057 & 0.293 \\
\hline Average & 58 & $3.42(0.73)$ & 57 & $2.61(0.90)$ & 5.318 & $0.000 *$ \\
\hline \multicolumn{7}{|l|}{ Frequency of use of IC evaluation procedures } \\
\hline Feedback on events & 58 & $3.93(1.23)$ & 58 & $3.07(1.41)$ & 3.510 & $0.001 *$ \\
\hline Employee surveys & 58 & $3.83(1.11)$ & 59 & $2.80(1.45)$ & 4.327 & $0.000 *$ \\
\hline Analytics of the sending of newsletters & 59 & $3.83(1.30)$ & 59 & $2.51(1.52)$ & 5.066 & $0.000 *$ \\
\hline Intranet analytics & 58 & $3.74(1.18)$ & 59 & $2.41(1.37)$ & 5.655 & $0.000 *$ \\
\hline Enterprise social networks metrics & 58 & $3.43(1.35)$ & 59 & $2.39(1.53)$ & 3.896 & $0.000 *$ \\
\hline Cost/benefit analysis & 58 & $2.55(1.34)$ & 58 & $1.91(1.25)$ & 2.655 & $0.009 *$ \\
\hline Average & 57 & $3.56(0.78)$ & 58 & $2.51(0.79)$ & 7.247 & $0.000 *$ \\
\hline \multicolumn{7}{|l|}{ Barriers to evaluation } \\
\hline Not having the right tools & 59 & $2.85(1.38)$ & 59 & $3.58(1.35)$ & $-2,901$ & $0.004^{*}$ \\
\hline Not understanding what to measure & 59 & $2.75(1.21)$ & 59 & $3.49(1.31)$ & $-3,217$ & $0.002 *$ \\
\hline The evaluation method is difficult to understand & 59 & $2.85(1.16)$ & 59 & $2.75(1.18)$ & 0.472 & 0.638 \\
\hline It takes a lot of time & 59 & $2.69(1.18)$ & 59 & $2.71(1.39)$ & -0.071 & 0.943 \\
\hline Reports cannot be carried out & 59 & $2.19(1.17)$ & 59 & $2.69(1.45)$ & -2.096 & $0.038 *$ \\
\hline Evaluating IC generates many costs & 59 & $2.19(1.12)$ & 59 & $2.49(1.39)$ & -1.310 & 0.193 \\
\hline Average & 59 & $2.58(0.89)$ & 59 & $2.95(0.87)$ & -2.263 & $0.025^{*}$ \\
\hline Quality and ability of the IC team & 59 & $3.83(0.85)$ & 59 & $2.73(1.14)$ & 5.934 & $0.000 *$ \\
\hline \multicolumn{7}{|l|}{ Role of IC in the company } \\
\hline Supports the strategic objectives & 59 & $4.27(0.89)$ & 59 & $3.49(1.21)$ & 3.994 & $0.000 *$ \\
\hline Allows the recognition of communicative aspects & 59 & $3.98(1.03)$ & 59 & $3.47(1.24)$ & 2.431 & $0.017^{*}$ \\
\hline Supports managers with information & 59 & $3.86(1.04)$ & 59 & $3.44(1.22)$ & 2.028 & $0.045^{*}$ \\
\hline Advises managers on how to act & 59 & $3.92(1.01)$ & 59 & $3.36(1.37)$ & 2.524 & $0.013 *$ \\
\hline Key in the digitalization of the company & 59 & $3.93(1.17)$ & 59 & $3.25(1.43)$ & 2.812 & $0.006 *$ \\
\hline Important role in the company's overall running & 59 & $4.05(0.96)$ & 59 & $3.12(1.38)$ & 4.271 & $0.000 *$ \\
\hline Involved in the strategic plans & 59 & $3.81(1.09)$ & 59 & $2.68(1.31)$ & 5.128 & $0.000 *$ \\
\hline Giving managers important recommendations & 59 & $3.63(0.98)$ & 59 & $2.85(1.23)$ & 3.808 & $0.000 *$ \\
\hline Being trusted advisors to senior managers & 59 & $3.59(1.21)$ & 59 & $2.86(1.38)$ & 3.052 & $0.003 *$ \\
\hline IC manager is one of the senior mangers & 59 & $3.41(1.23)$ & 59 & $2.64(1.37)$ & 3.173 & $0.002 *$ \\
\hline Acts only when problems occur & 59 & $2.37(1.41)$ & 59 & $2.75(1.46)$ & -1.411 & 0.161 \\
\hline Average & 59 & $3.71(0.72)$ & 59 & $3.08(0.93)$ & 4.117 & $0.000 *$ \\
\hline
\end{tabular}

**High effectiveness: companies whose assessment of the effectiveness of its IC strategy is between 4 and 5 . Medium-low effectiveness: companies whose assessment of the effectiveness of its strategy of IC is between 1 and 3 . 
On the other hand, it should be noted that highly effective companies value the quality and skills of the IC teams more, considering IC to be of great relevance to the company.
The departments of $\mathrm{Cl}$ prioritize in their short-term objectives the union of the $\mathrm{Cl}$ with the business strategy

The results of the study also reflect that companies with the most effective teams prioritize three prominent objectives:

- managing digital evolution and the media (89.8\%);

- strengthening the role of communication to support senior managers' decision-making (88.1\%);

- integrating employee generated content into corporate communication (76.3\%).

\section{Conclusions}

The results of this study show that IC is an area that is becoming increasingly important in business as a strategic management tool. With this in mind, knowing how to perform the evaluation of its effectiveness can contribute to consolidating its influence. In fact, evaluating results is the only way for communication professionals to demonstrate the value that their work brings to the organisation and to the profit and loss account (Castillo-Esparcia; Álvarez-Nobell, 2014; Castillo-Esparcia; Villabona-Beltrán, 2018; Marca et al., 2017).

Only what is measured can be valued, managed, and, therefore, improved, as reminded by the Association of Consulting Companies in Public Relations and Communication (Adecec, 2016, p. 7). Therefore, measuring and evaluating the results of communication is fundamental to achieving efficiency (Álvarez-Nobell; Lesta, 2011).

Taking the degree of effectiveness in IC teams into consideration, the results of this research highlight that the companies in which IC has a higher effectiveness are those that evaluate more, that value the teams highly and are those in which IC plays a more significant role. This data contrasts with the lack of interest in measurement demonstrated by European communication professionals, where only $16.8 \%$ considered implementing routines for measurement and evaluation relevant (Zerfass; Verčič; Volk, 2017). As Castillo-Esparcia \& Villabona-Beltrán (2018) caution, understanding how communicators do their work will be far from simple if only such a small part of them measures the impact of their activities.

To evaluate the effectiveness of IC strategies, companies mainly evaluate the use of a channel, such as the intranet, and their own employees, a fact that coincides with previous research (Zerfass et al., 2015). In this last point they take particular note of employee satisfaction, the understanding of key messages and employee changes in attitude, which are some of the key results IC pursues. In this sense, it has been observed that multinationals and companies that have an IC department carry out a wider assessment of some of these aspects.

In addition, the companies that have participated in this study make their employees central to the evaluation through such instruments as participatory feedback and surveys. In this case, the utilisation of these assessment tools tends to be higher in multinationals and in companies with IC departments, as well as those in which IC is centralised.

The fact that Spanish companies focus on measuring the satisfaction of the internal audiences is good news because, as Álvarez-Nobell \& Lesta (2011) point out, any effective evaluation of communication should include this element, along with the use of resources and outputs.

This study shows the main barrier faced by companies to carry out the evaluation of IC, in line with previous research (Castillo-Esparcia; Villabona-Beltrán, 2018), is not having adequate tools to measure effectiveness and not being clear what it is they have to measure. Not knowing exactly what to assess is one of the greatest difficulties firms face when it comes to realising an effective internal communication evaluation.

Also, lack of time appears as a limitation in assessing results, while the costs which the evaluation in itself generates are not listed as a priority problem by professionals in the field. It is noted that the companies that experience greater barriers in evaluating are those that are national in scope and those which do not have an IC department.

On the other hand, this research has shown that the most common priorities in IC departments in the medium term, as the editions of the previous years of the European communication monitor (Zerfass et al., 2018) elaborate, are those related to consolidating its strategic role (in particular, closer alignment with the business strategy and a strengthened role in decision making) and, the least common, issues related to ethics (implementing ethical codes and sustainability policies). It is surprising that "establishing new methods to evaluate and demonstrate the value of communication" and "explaining the value of IC to the directors" does not top the list of priorities, when these are essential for adding value to IC and facilitating improved management, although $74.0 \%$ of respondents considered this to be an important challenge in coming years.

In short, this study reflects that the evaluation of the results of IC is a subject that is receiving a growing interest in Spanish companies, but it is still not considered a priority in the immediate agenda of IC departments. In addition, companies 
find barriers to conducting effective IC assessments, and when the results are measured and evaluated, evaluation is on concrete actions or plans and it is only on rare occasions the contribution to the business strategy is measured. In the face of this reality, the academic field ought to promote the study of evaluation procedures that the companies are applying in internal communication, to assess their effectiveness and to be able to develop measurement models that are already applied in other strategic areas of the company, such as the balanced scorecard (Álvarez-Nobell; Lesta, 2011) that allows standardised assessments and demonstrates IC's contribution to the company results. Conducting investigations such as this, with larger samples and in other countries, as well as studying specific cases present future lines of research to develop in order to deepen the knowledge of this area and move forward in ways of assessing internal communication.

The main limitations of this research are in the choice of the sample. There is no a record of communication managers in Spain. The study is limited to professionals who are part of the Dircom association, and therefore the sample is bounded and cannot be considered probabilistic.

\section{Note}

1. The participants have qualified the relevance of the objectives for the next three years, identifying those which are priority issues (evaluated with a score of 4 or 5 , in an order of importance from 1 to 5 ), those which have medium importance (evaluated with a score of 3 ) and those that are secondary (evaluated with a score of 1 or 2).

\section{References}

Adecec (2016). Guía práctica de la medición. Asociación de Empresas Consultoras en Relaciones Públicas y Comunicación. http://adecec.com/wp-content/uploads/2018/10/Gui\%CC\%81a-PRa\%CC\%81ctica-de-la-Medicio\%CC\%81n-def_.pdf

Adecec (2019). La comunicación interna. Gran aliada en los nuevos modelos de negocio. Asociación de Empresas Consultoras en Relaciones Públicas y Comunicación.

http://adecec.com/wp-content/uploads/2019/03/Cl_ADECEC.pdf

Álvarez-Nobell, Alejandro; Lesta, Laura (2011). “Medición de los aportes de la gestión estratégica de comunicación interna a los objetivos de la organización". Palabra clave, v. 14, n. 1, pp. 11-30.

https://dialnet.unirioja.es/servlet/articulo?codigo=3713667

Berceruelo, Benito (coord.) (2014). Nueva comunicación interna en la empresa. Madrid: Estudio de Comunicación/Biblioteca Aedipe de RRHH. ISBN: 9788469709405

https://www.estudiodecomunicacion.com/wp-content/uploads/2018/01/140801ARF-ESTUDIO-interior-comuni-interna-1.pdf

Berger, Bruce (2008). Employee/organizational communications. Institute for Public Relations, pp. 1-23.

https://instituteforpr.org/employee-organizational-communications

Capriotti, Paul (1998). “La comunicación interna”. Reporte C\&D - Capacitación y desarrollo, v. 13, pp. 5-7. http://www.bidireccional.net/Blog/Comunicacion_Interna.pdf

Carrillo-Durán, María-Victoria (2016). “Importancia del profesional de la información en la dirección de comunicación de las organizaciones". El profesional de la información, v. 25, n. 2, pp. 272-278.

https://doi.org/10.3145/epi.2016.mar.14

Carrillo-Durán, María-Victoria; Nuño-Moral, María-Victoria (2010). “La documentación en la evaluación y gestión de la imagen corporativa". El profesional de la información, v. 19, n. 2, pp. 123-132.

https://doi.org/10.3145/epi.2010.mar.02

https://recyt.fecyt.es/index.php/EPI/article/view/epi.2010.mar.02

Castillo-Esparcia, Antonio; Álvarez-Nobell, Alejandro (2014). Evaluación en comunicación estratégica. London: McGraw Hill Education. ISBN: 9788448194130

Castillo-Esparcia, Antonio; Villabona-Beltrán, Diego (2018). “Evaluación para demostrar la efectividad en comunicación y relaciones públicas. Una mirada a las prácticas profesionales desde los European Communication Monitor". Communication papers, v. 7, n. 15, pp. 137-153.

http://ojs.udg.edu/index.php/CommunicationPapers/article/view/446

Charry-Condor, Héctor-Omar (2018). “La gestión de la comunicación interna y el clima organizacional en el sector público". Comunicación, v. 9, n. 1, pp. 25-34.

Couper, Mick P. (2000). Web surveys: The questionnaire design challenge. http://isi.cbs.nl/iamamember/CD2/pdf/263.pdf

Cuenca, Joan; Verazzi, Laura (2018). Guía fundamental de la comunicación interna. Barcelona: Editorial UOC. ISBN: 978 8491802723 
Daly, Finbarr; Teague, Paul; Kitchen, Philip (2003). "Exploring the role of internal communication during organisational change". Corporate communications: An international journal, v. 8, n. 3, pp. 153-162. https://doi.org/10.1108/13563280310487612

Elving, Wim J. L. (2005). "The role of communication in organisational change". Corporate communications: An international journal, v. 10, n. 2, pp. 129-138.

https://doi.org/10.1108/13563280510596943

Gatehouse (2019). State of the sector 2019. The definitive global survey of the internal communication profession. Vol. 11. https://www.gatehouse.co.uk/download-state-sector

Gómez-De-la-Fuente, María-del-Carmen; Túñez-López, Miguel (2012). “Auditoría de comunicación, un proceso básico para la eficacia y eficiencia de la comunicación estratégica de las organizaciones". En: Actas IV Congreso internacional Latina de comunicación social: comunicación, control y resistencias, p. 70. Sociedad Latina de Comunicación Social. Universidad de La Laguna.

http://www.revistalatinacs.org/12SLCS/2012_actas/070_Tunez.pdf

IC Kollectif (2018). The next level: The business value of good communication. https://www.ickollectif.com/report

IC Kollectif (2019). Measurement. Linking internal communication to business results. Global research report. https://www.ickollectif.com/linking-ic-business-results

Marca, Guillem; Oliveira, Andrea; Matilla, Kathy; Miranda, Thais (2017). "El valor de la evaluación de las relaciones públicas y de la comunicación en las organizaciones: el caso de los hospitales del Sistema Nacional de Salud Español". Palabra clave: revista de comunicación, v. 20, n. 2, pp. 506-528.

https://doi.org/10.5294/pacla.2017.20.2.9

Martínez-Martínez, Luz-Ángela; Fernández-Hurtado, Saul-Rick (2018). "Internal communication issues in the firms: Does it affect the productivity?". Review of European studies, v. 10, n. 2, pp. 1-13.

https://pdfs.semanticscholar.org/9b36/5d3a6c9076a56969f05250e830931407825f.pdf

Men, Linjuan-Rita (2014). "Strategic internal communication: Transformational leadership, communication channels, and employee satisfaction". Management communication quarterly, v. 28, n. 2, pp. 264-284.

https://doi.org/10.1177/0893318914524536

Men, Linjuan-Ritta; Stacks, Don (2014). "The effects of authentic leadership on strategic internal communication and employee-organization relationships". Journal of public relations research, v. 26, n. 4, pp. 301-324.

https://doi.org/10.1080/1062726X.2014.908720

Nelli, Roberto-Paolo (2018). Internal communication in Europe. Key success factors and managerial approaches. Ascai; European Association for Internal Communication. ISBN: 9788834336410 http://www.ascai.it/uploads/files/RAPPORTI\%20ASCAI/E_BOOK\%20IC\%20EUROPEAN\%20REPORT\%202018.pdf

O'Neil, Julie; Ewing, Michele; Smith, Stacey; Williams, Sean (2018) “A Delphi study to identify standards for internal communication". Public relations journal, v. 11, n. 3.

https://prjournal.instituteforpr.org/wp-content/uploads/1.-A-Delphi-Study-to-Identify-Standards-for-IC-.pdf

Rodríguez-Jaume, María-José; González-Río, María-José (2014). “Las encuestas autoadministradas por internet. Un estudio de caso: las familias adoptivas y sus estilos de vida". Empíria. Revista de metodología de ciencias sociales, v. 29, pp. 155-175.

https://doi.org/10.5944/empiria.29.2014.12944

Ruck, Kevin; Welch, Mary (2012). "Valuing internal communication; management and employee perspectives". Public relations review, v. 38, n. 2, pp. 294-302.

https://doi.org/10.1016/j.pubrev.2011.12.016

Sedej, Tanja; Justinek, Gorazd (2013). "Social media in internal communications: A view from senior management". In: Bondarouk, Tanya; Olivas-Luján, Miguel R. (eds.). Social media in human resources management, pp. 83-95. ISBN: 978 1781909010 https://doi.org/10.1108/S1877-6361(2013)0000012008

Simancas-González, Esther; García-López, Marcial (2017). “Gestión de la comunicación en las universidades públicas españolas". El profesional de la información, v. 26, n. 4, pp. 735-744.

https://doi.org/10.3145/epi.2017.jul.17

Slijepčević, Milica; Bovan, Ana; Radojević, Ivana (2018). “Internal communications as a factor of company's efficiency”. Marketing, v. 49, n. 2, pp. 124-143. 
VMAGroup (2018). The view.

http://www.vmagroup.com/the-view

Watson, Tom; Noble, Paul (2014). Evaluating public relations: A guide to planning, research and measurement. Kogan Page Publishers. ISBN: 9780749468897

Zerfass, Ansgar; Verčič, Dejan; Verhoeven, Piet; Moreno, Ángeles; Tench, Ralph (2015). European communication monitor 2015. Creating communication value through listening, messaging and measurement. Results of a survey in 41 countries.

http://www.zerfass.de/ECM-WEBSITE/media/ECM2015-Results-ChartVersion.pdf

Zerfass, Ansgar; Verčič, Dejan; Volk, Sophia-Charlotte (2017). "Communication evaluation and measurement". Corporate communications: An international journal, v. 22, v. 1, pp. 2-18.

https://doi.org/10.1108/CCIJ-08-2016-0056

Zerfass, Ansgar; Tench, Ralph; Verhoeven, Piet; Verčič, Dejan; Moreno, Ángeles (2018). European communication monitor 2018. Strategic communication and the challenges of fake news, trust, leadership, work, stress and job satisfaction. Bruselas: EACD/Euprera, Quadriga Media.

http://www.communicationmonitor.eu/2018/06/13/ecm-european-communication-monitor-2018

\section{Colección de libros de bolsillo El profesional de la información (Editorial UOC) Últimos títulos publicados}
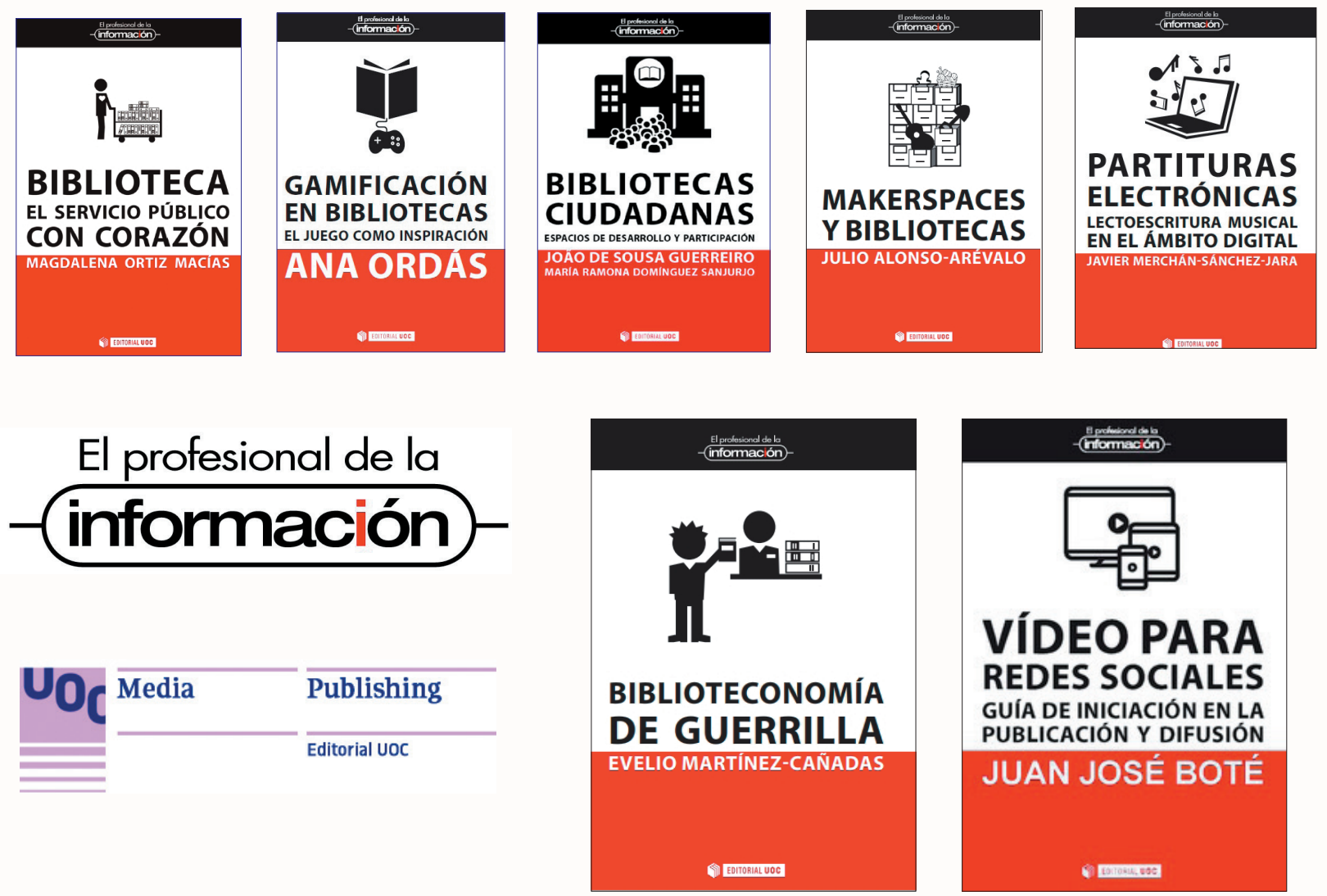

Más información:

http://www.elprofesionaldelainformacion.com/libros.html 